\title{
Effectiveness of mindfulness based stress reduction on executive function, cognitive flexibility in women with neuroticism trait in Esfahan city
}

\author{
Maryam Najafi ${ }^{1}$, Maryam Ghorbani ${ }^{2}$, Sedigheh Rezaei Dehnavi $^{3}$ \\ 1-M.A in general psychology,, payam noor university, Tehran, Iran. ORCID: 0000-0002-7278-1024 \\ 2-Assist.prof, Department psychology, payam noor university, Tehran.Iran. ORCID: 0000-0002-3288-4176 \\ E-mail: ghorbani_psyc@yahoo.com \\ 3-Assist.prof, Department psychology, payam noor university, Tehran, Iran. ORCID: 0000-0002-2714-7665
}

Received: 06/01/2018

Accepted: 25/09/2018

\begin{abstract}
Abestract
Introduction: The neuroticism is persons tend to experience the negative emotions as anxiety, depression and anger and considered as a risk factor for a wide spectrum from affective disorders.

Aim: The purpose of this study wase to determine the effectiveness of mindfulness based stress reduction on executive function, cognitive flexibility in women with neuroticism.

Method: The method this research was quasi -experimental with per -test and post -test follow -up design whit control and experimental groups. The statistical population consisted of all women with neuroticism in Esfahan city in spring 2017 that among they 30 women with this trait selected with available sampling and were randomly devidfd in to an experimental and a control group (15 each). All subject assessed in each group by stroop test (lezak, 2004), the tower of London test ( Tehrani doost at all , 2003 )at pre and past test. for experimental group conducted mindfulness based strees reduction sessions.

Results: According to the finding this research could use from mindfulness based stress reduction on executive function and cognitive flexibility in women.

Conclusion: The result of analysis of covariance showed that at post test, the experimental group showed a significant improvement in self efficacy and its sub-scales inclouding executive function and cognitive flexibility $(\mathrm{p}<0 / 05)$.
\end{abstract}

Keywords: Mindfulness based stress reduction, executive function, cognitive flexibility, neuroticism trait.

\footnotetext{
How to cite this article : Najafi M, Ghorbani M, Rezaei Dehnavi S. Effectiveness of mindfulness based stress reduction on executive function, cognitive flexibility in women with neuroticism trait in Esfahan city.. Shenakht Journal of Psychology and Psychiatry. 2018; 5 (3): $22-37$. URL :http://shenakht.muk.ac.ir/article-1-431-fa.pdf
}

Copyright $(\odot 2018$ the Author (s). Published by Kurdistan University of Medical Sciences. This is an open access article distributed under the terms of the Creative Commons Attribution-Non Commercial License 4.0 (CCBY-NC), where it is permissible to download, share, remix, transform, and buildup the work provided it is properly cited. The work cannot be used commercially without permission from the journal. 


\title{
اثربخشى مداخلهى ذهن آكاهى مبتنى بر كاهش استرس بر عملكردهاى اجرايى و انعطافيذيرى شناختى در زنان داراى خصيصهى نوروز ترايى در شهر اصفهان
}

\author{
مريم نجفى '، مريم قربانى'، صديقه رضايى دهنوى" \\ ا. ا. كارشناسى ارشد روانشناسى عمومى، دانشكاه بيام نور، تهران، ايران.

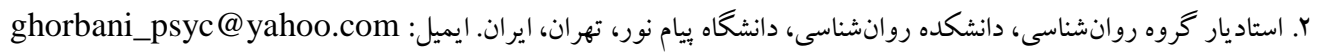

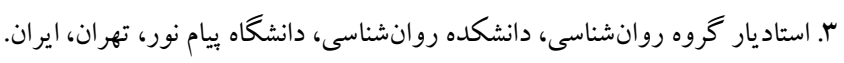

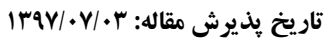

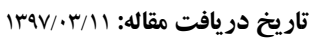

\section{جكيده}

مقدمه: نوروز گرايى تمايل فرد به تجربه هيجانهاى منفى مانند اضطراب، افسردگى و خشم است و بهعنوان يكك عامل خطر آفرين براى طيف گستردهاى از اختلالات عاطفى در نظر خر فته مى شود.

هدف: هدف ئزوهش حاضر بررسى تأثير مداخلهى ذهن آكاهى مبتنى بر كاهش استرس بر عملكردهاى اجرايى و انعطافيذيرى شناختى در زنان داراى خصيصهى نوروز گر ايى در شهر اصفهان بود.

روش: روش ئزوهش از نوع نيمه آزمايشى با بيش آزمون- يس آزمون همراه با گروه آزمايش و كنترل بود. جامعهى آمارى شامل

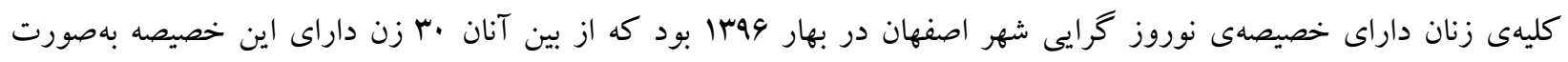

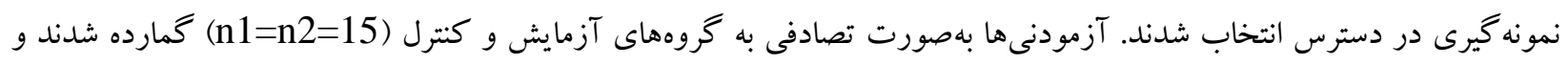

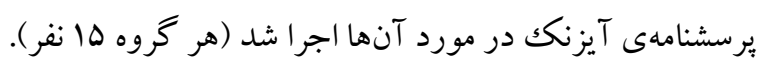

آزمودنى ها در هر گروه قبل و بعد از مداخله بهوسيلهى آزمونهاى برج لندن و استروٍ يِيجيده مورد آزمون قرار گَرفتند. هشت جلسه

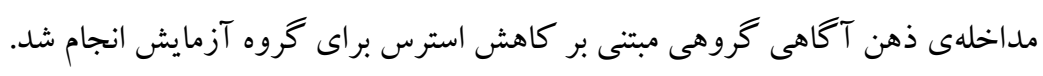
يافته ها: نتايج تحليل كوواريانس نشان داد در مرحلهى يس آزمون گروه آزمايش بهبود معنادارى در متغيرهاى عملكردهاى اجر ايى و

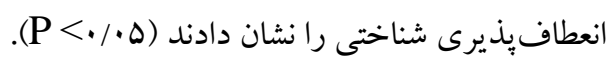

نتيجه كيرى: با توجه به يافتهاى اين بثزوهش مىتوان از مداخلهى ذهن آكاهى مبتنى بر كاهش استرس براى افزايش عملكردهاى اجرايى و انعطاف يذيرى شناختى در زنان استفاده كرد. كليدوازهها: ذهن آكاهى مبتى بر كاهش استرس - عملكردهاى اجرايى- انعطاف يذيرى شناختى -خصيصهى نوروز گرايى 
حلقه احشايى-قشرى (رابط درونى قشر مغز با مغز احشايى يا ساختارهاى مرتبط با دستخاه كنارى) مرتبط

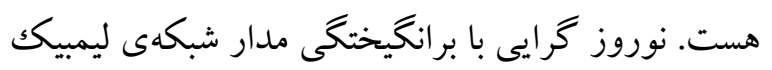

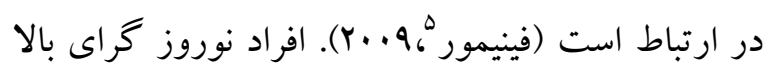

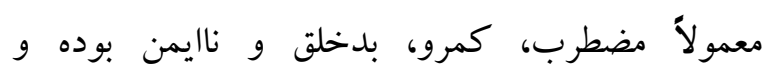
واكنشيذيرى بالاتر و تحمل پِيينى نسبت به حوادث

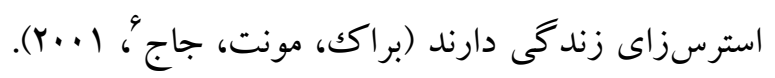
نوروز گرايى با تأثيرات گستردهاى كه روى خلق، شناخت و فرايندهاى عصبى - زيستى مى گذارد به عنوان يكك عامل خطر آفرين براى طيف گستردهاى از اختلالات

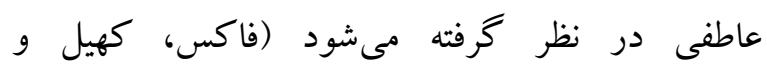

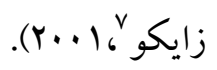

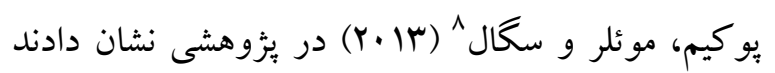
كه نوروز گرايى و افسردگى داراى ارتباطى منحصر به فرد با عملكردهاى اجر ايى در بزر كُسالان هست. كاركردهاى اجرايى را فرايندهاى شناختى قشر ويشانى

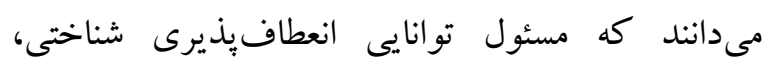
آغازگرى، خود توليدى، بازدارى بِاسخ و نظم دادن

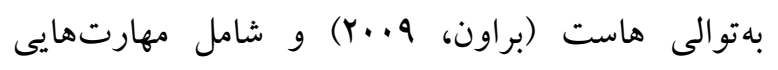
ازجمله آغاز گرى، تمركز، هشيارى، تعديل احساسات،

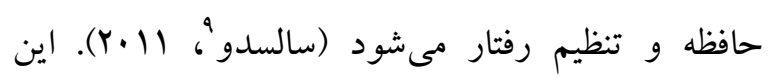
كاركردها فرايندهاى هدف مدار عصب شيناختى هستند كه وظيفهى اصلى آنها كنترل و هماهنگگ رفتار است

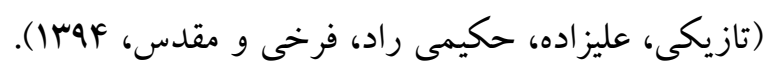

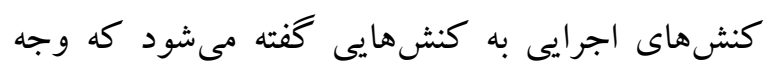
مشترك همدى آنها مهار ارادى رفتارها، افكار و و إنى هيجانهاست. اين مهار گرى، معطوف به هدف و مستلزم

${ }^{5}$.Finomore

${ }^{6}$.Barrick, Mount \& Judge

${ }^{7}$.Fox, Cahill \& Zougkou

${ }^{8}$.Yochim, Mueller \& Segal

${ }^{9}$.Saldeso

\section{مقدمه} امروزه اضطراب و تنيدگى روانى جزء جدانشدنى زندگى مهى بر شده است و در تعيين سلامت و بيمارى افراد اهميت

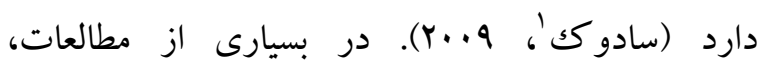
مضطرب بودن به عنوان صفتى جهت تبين خلق افراد

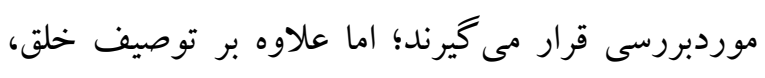
اضطراب بهعنوان يكى خصيصه نيز اندازه گيرى مىشود. خصيصها، گر ايشهايى براى نشان دادن الخوهاى ثابت افكار، احساسات و اعمال هستند. (اميدوارى و همكاران، •وب1). اضطراب صفت، نوعى صفت و بريايى شخصيتى. است و به تفاوتهاى نسبتاً ثابت فردى در آمادكى براى

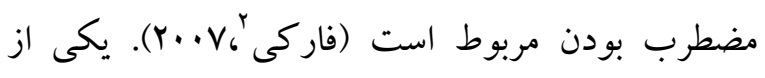
ابعاد اساسى شخصيت كه توسط آيزنك مطرح شد، نوروز كرايى هست كه داراى يكك بخش بيجيدهى

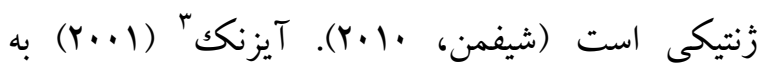
تحقيقات متعددى اشاره كرد كه شواهدى براى مبناى زنتيكى صفات نوروز گرايى مانند اضطراب، هيسترى و اختلالات وسواس فكرى - عملى يافتهاند. نوروز كرايى به ميه تمايل فرد به تجربه هيجانهاى منفى مانند اضطراب، افسردگى و خشم برمى گردد (مكك كرايى و جانَ' ra91). افرادى كه در نوروز گرايى نمره بالا مى گيرند، اغلب واكنش هيجانى مفرط نشان مىدهند و بعد از برانگيختكى هيجانى، بهسختى مىتوانند به حالت طبيعى

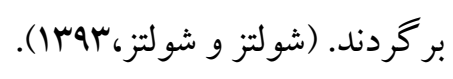
بر اساس ديدگاه آيزنك تفاوت هاى فردى با فعاليت دو محور عصبى يعنى حلقه قشرى-شبكه اى (رابط قشر مغزى، تالاموس و دستگاه شبكهاى فعالساز صعودى) و

\footnotetext{
${ }^{1}$.Sadock

${ }^{2}$.Farki

${ }^{3}$.Eyzenk

${ }^{4}$.Mc Crar \& John
} 
افراد از آن براى حل مشكلات زندگى استفاده مى كنند.

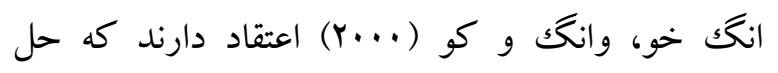
موفقيت آميز مساله موجب افزايش توانايى افراد در حيطه

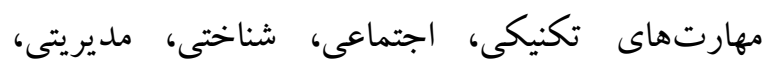
تحقيقى و آموزشى مى گردد. حل مساله و تصميم گيرى به عنوان عناصر مهم كاركردهاى اجرايى وابسته به

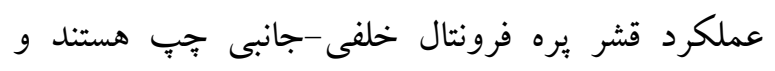
تمرينهاى مؤثر بر لوب بيشانى درواقع نوعى تمرين براى

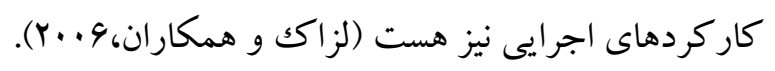
لزاكى و همكاران (Y..V) كنش اجرايى حل مساله و برنامهريزى را بهعنوان توانايى شناسايى و سازماندهى مراحل و عناصر موردنياز براى انجام يكك قصد يا رسيدن به يكك هدف تعريف مى كنند. هرجند كاركردهاى اجرايى با كاركرد قشر بيشانى 19

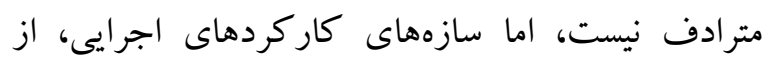
تحليل بيامدهاى آسيب به قشر بيشانى ناشى شد (زلازد،

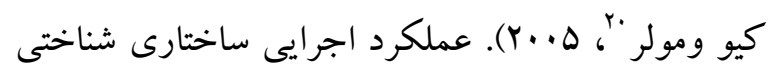
است كه از آن براى توضيح رفتارهايى كه وابسته به

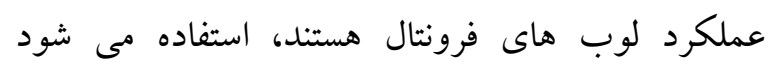

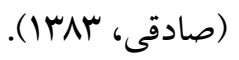

آسيب در كاركرهاى اجر ايى مىتواند بيامدهاى فراوان اى در عملكرد اجتماعى، هيجانى و شناختى فرد داشته باشد

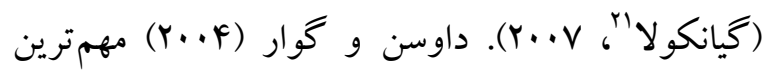
اين كاركردها را به شكل برنامهريزى، سازماندهى، انعطافيذيرى، حافظه فعال، مديريت زمان، بازدارى ياسخ، آغاز گرى تكليف و مقاومت مبتنى بر هدف

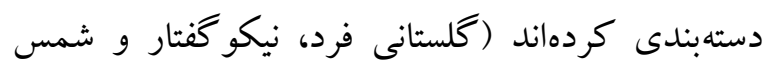

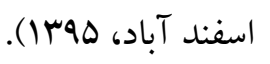

${ }^{19}$. prefrontal

20. Zelazo,Qu, Muller

${ }^{21}$. Giankola
تلاش و به كارگيرى نيروهاى ذهنى است. براى انجام

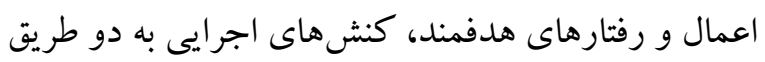
به ما كمكك مى كند؛ اول، استفاده از مهارتهاى فكرى معين براى انتخاب و رسيدن به اهداف يا حل مسئله كه

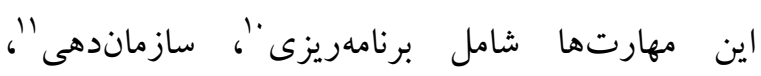

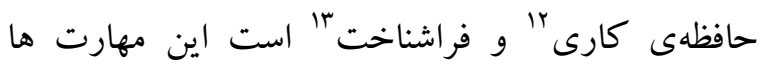
شامل بازدارى باسخ "ا خود نظم جويى هيجانى هار، راه

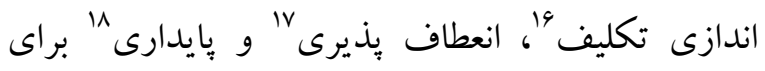

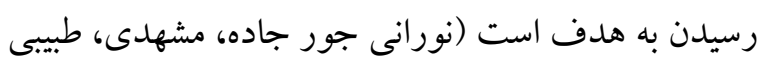

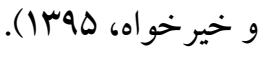
مفهوم كاركردهاىهاى اجرايى بهعنوان يكك سازمى نظرى توانسته است بين ساختارهاى مغزى (بهويزه نواحى بيشانى و ويش بيشانى) و كاركردهاى روانشناختى از قبيل حل مسئله، تفكر انتزاعى و تغيير مجموعه، حلقه ارتباطى نيرومندى به وجود آورده و از اين راه به دركك بهتر آسيبشناسى روانى كمكك كند (رعيت معينى، حسن آبادى، آقا محمديان شعرباف، سهوبا (). كاركرد اجرايى يكى از اجزاى كليدى تنظيم تفكر و فعاليت هست و تأكيد روى بردازش شناختى دارد كه با حل مسئله مرتبط است (رفيعى نيا، زحمت بر، رحيميان

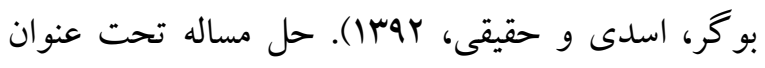

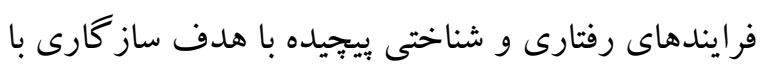
جالشهاى درونى و بيرونى تعريف مى گردد (هاينر، هى،

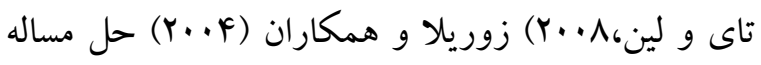
را به عنوان فرايند خود جهت جهى شناختى-رفتارى كه

\footnotetext{
${ }_{11}^{10}$.planning

11. ordanization

${ }^{12}$.Working memory

13. meta cognition

${ }^{14}$.Respanse inhibition

15 . self - regulation

16. Task initiation

17. Flexibility

${ }^{18}$.Goal - directed persis tence
} 
ون اثربخشى مداخلهى ذهن آكاهى مبتنى بر كاهش استرس بر عملكردهاى اجر ايى و انعطافيذيرى شناختى در زنان داراى خصيصهى نوروز گرايى در شهر

اصفهان

براى تطابق با موقعيتهاى جديد و تنظيم انتظارات بر اساس تغييرات و شرايط جديد محيطى ضرورى است

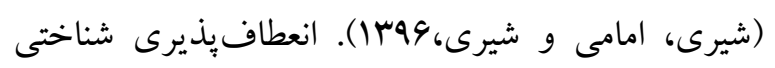
يكك عملكرد منحصربهفرد، صفت بارز يا توانايى شناخت

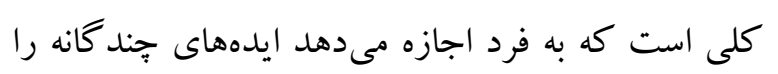
بيذيرد، بهطور انعطاف بذير شناخت را تغيير دهد و هنگام

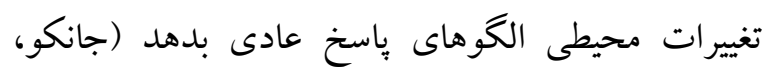

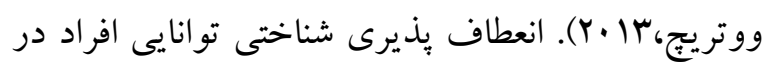

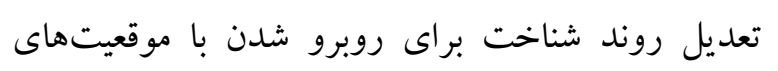
جديد و غيرقابل بيشبينى هست (كانز، +..Y). شواهدى وجود دارد كه نشان مىدهد انعطاف يذيرى با بهزيستى

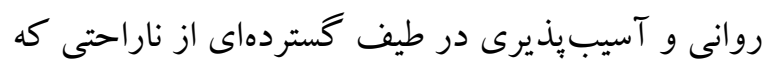

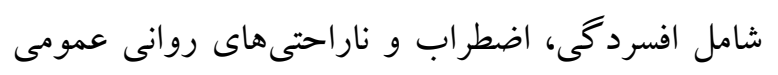
مىشود، رابطه دارد (ماسوداو تالى، Y Y.r). كاركردهاى شناختى مغز كه در اختلالات كوناگون دجار اشكال مى شود مىتواند با مراقبه ذهن آكاهى بهبود درد

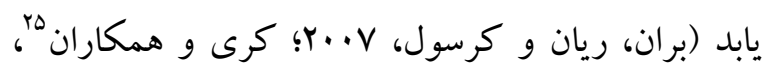

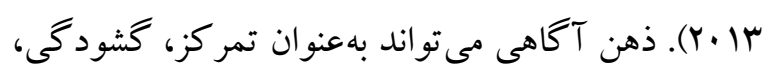

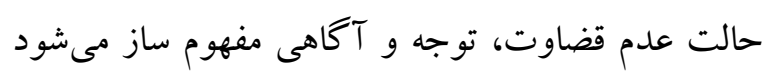

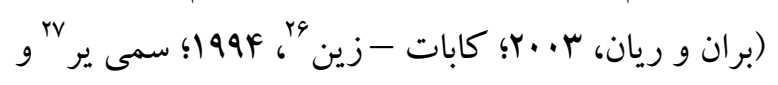

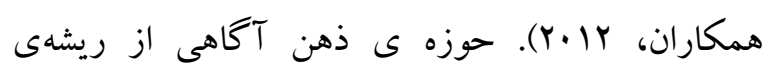
بودائى نشأت كرفته و به عنوان يكك تكنيك مديريت

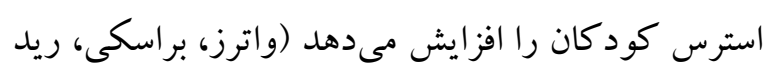

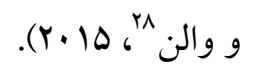
اخر جُه مفهوم اصلى ذهن آكاهى (براى مثال بيشاب و و

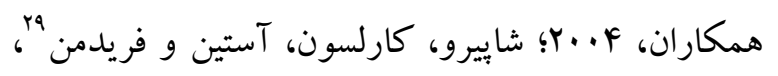

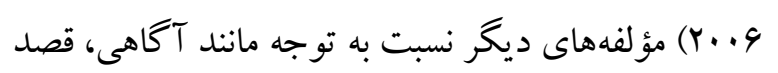

${ }^{25}$.Brown, Ryan, Cray at all

${ }^{26}$.Kabat-Zinn

${ }^{27}$.Sedlmeire at all

${ }^{28}$.Watters, Braski, Reed \& Allen

${ }^{29}$.Shapiro, Karelson, Astean \& Fridman مطالعه در جمعيتهاى بالينى نشان داده است كه عملكرد

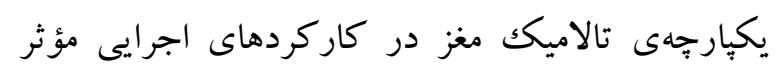
است. بر اساس ئوهشهاى جديد اين بخش نسبت به هيبو كامب در رابطه با كاركردهاى اجرايى دارد (تاج

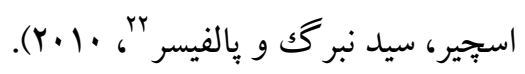

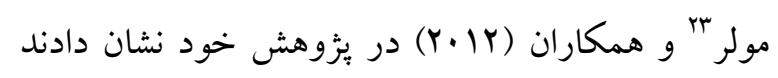

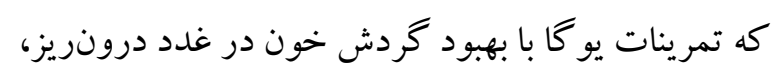

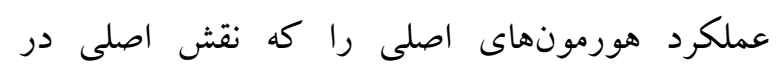
فيزيولوزى مشكلات خلقى ايفا مى كنند، افزايش مىدهد. اين نتايج باعث بهبود خلق و به دنبال آن بهبود عملكرد

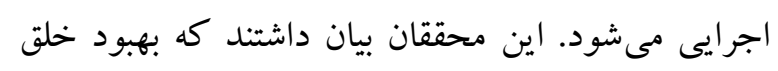

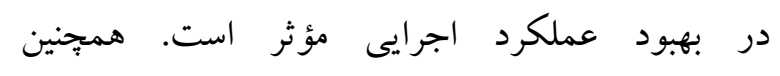
كاركردهاى اجرايى شامل توانايى برنامهريزى است

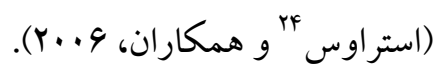
برنامهريزى در جهان واقعى اغلب شامل مدلسازى و

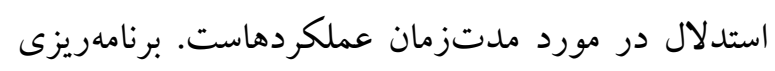
شامل ايجاد راهكارى مناسب جهت شروع و بيايان اعمال است. اخرجّه در تعدادى از موارد كاربردى مدتزمان

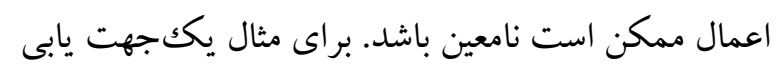

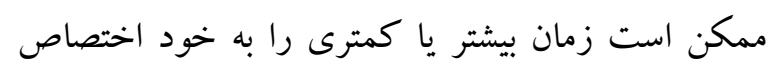
دهد و وابسته به شرايط بيرونى باشد (كيماتى و

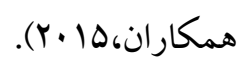
يُزوهشخران بر نقش حياتى لوب فرونتال در مهارتهايى مانند حافظه كارى، توجه، حل مشكل، استدلال كلامى،

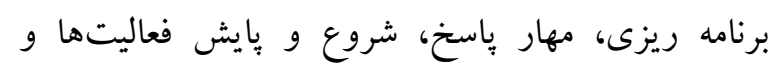

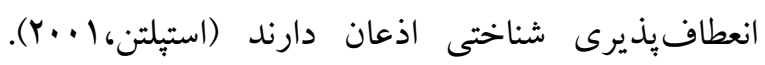
انعطاف بذيرى شناختى بهمثابه يكى از زيرمجموعهدهاى

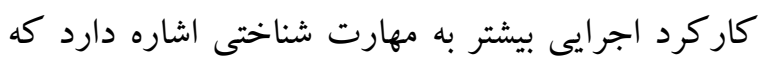

\footnotetext{
${ }^{22}$.Tuchscher, Seidenberg \& Pulsipher

${ }^{23}$.Mullur

${ }^{24}$.Steravos
} 
فرايندهاى بردازشى غير خود كار روشن مىشود؛ بنابر اين مىتوان انتظار داشت اگر آموزش ذهن آكًاهى توانايى

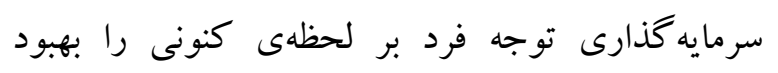
ببخشد، براثر تمرين بتواند با افزايش انعطاف يذيرى برى برى

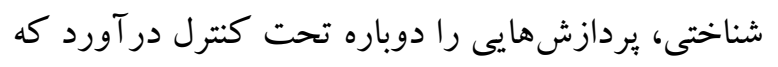

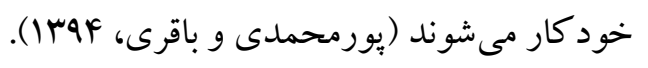
تحقيقات نشان مىدهد كه مراقبه ذهن آكاهى، استرس و و

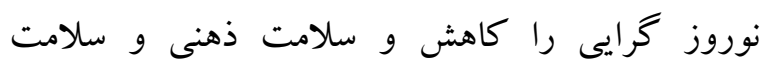

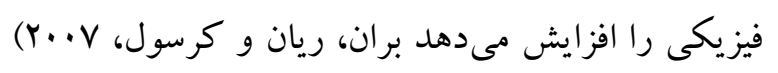
نتايج يزوهش اميرى، ربيعى و ديناوى (19 (Y)، در مورد

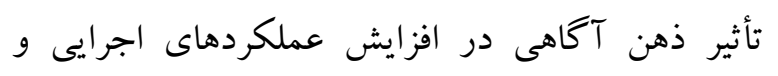
كاهش نشانگان افسردگى و نوروز گرايى در بيماران مولتى يل اسكلروزيس (MS) نشان دادكه به كار بردن آموزش ذهن آكاهى مىتواند براى كاهش سطوح افسردگى و نوروز گرايى در بيماران داراى MS كاملاً مفيد باشد.

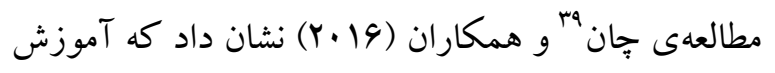
كنترل توجه ذهن آكاهانه با افزايش فعاليت آميگدال در

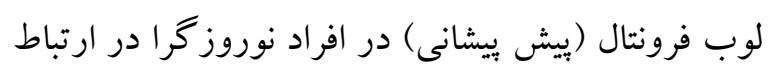
است. با توجه به ارتباط عوامل مرتبط ذكرشده كه متأثر از درمان ذهن آكَاهى مىباشند و با در نظر گُرفتن عملكرد افراد داراى نوروز گرايى در اين عوامل و فرايندها، بررسى اين عوامل منطقى به نظر مىرسند. لذا اين بزوهش در بى باسخگويى به اين سؤال است كه آيا مداخلهى ذهن آكاهى مبتنى بر كاهش استرس، بر عملكردهاى اجرايى و انعطاف يذيرى شناختى افراد خصيصهى نوروز

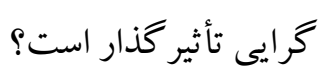

${ }^{39}$.Chan
و يا بذيرش را شامل مىشود، بيشتر تعاريف ذهن آكاهى

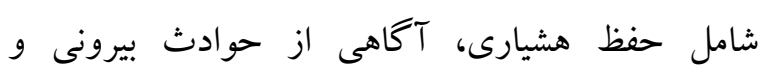
تجربيات درونى را شامل مىشود (جان كاسكى و هولز ‘' . ( $($. IF به نظر مىرسد مكانيسم اصلى ذهن آكَاهى خود كنترلى توجه باشد، جرا كه متمركز كردن توجه روى يك لك محر كى خنثى مثل تنفس، يكى محيط توجهى مناسب به

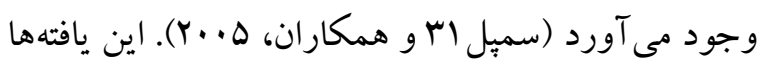
نشان مىدهد كه توجه ذهن آكاهى از تنظيم توجه در دو بعد زمان و وسعت در جمعيت بالينى و غير بالينى در

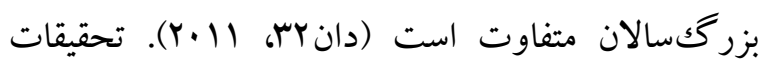
نشان مىدهد كه وقتى مردم در حالت ذهن آكَاهى هستند، تعداد محرككهاى جهان درونى و محيط بيرونى كه به آن توجه مى كنند افزايش مىيابد. (. نزلككسم،

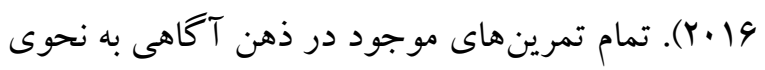
طراحىشدهاند كه توجه به بدن را افزايش مى دهند. در

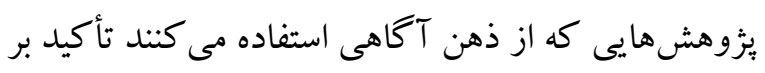
تعامل بين فرايندهاى بدنى، شناختى و هيجانى است

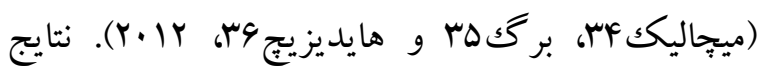

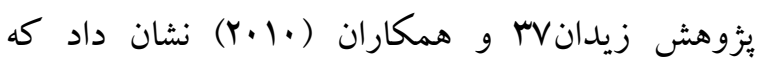

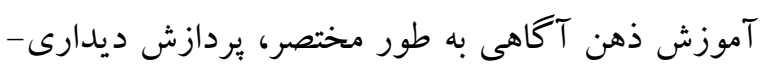

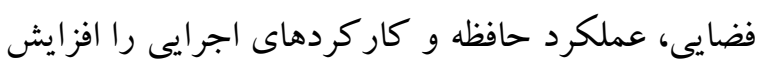
مىدهد. لذا با در نظر كرفتن تعريف ذهن آكاهى به عنوان جلب توجه كامل فرد به تجربه لحظهبهلحظه

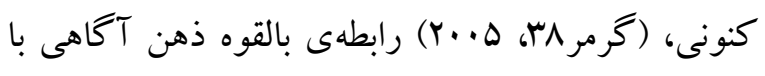

\footnotetext{
${ }^{30}$.Jankowski \& Holls

31 . Sample

${ }^{32}$.Down

${ }^{33}$. Nezlek

${ }^{34}$. Michalak

35 . Burg

36 . Heidenreich

${ }^{37}$.Zeidan

${ }^{38}$. Germer
} 
يرسشنامه شخصيت آيزنك: نسخه تجديد نظر شده ى برسشنامه ى شخصيتى آيزنك (EPQ-R) : اين برسشنامه ابتدا به وسيله ى آيزنك و آيزنك طراحى شد. نسخه

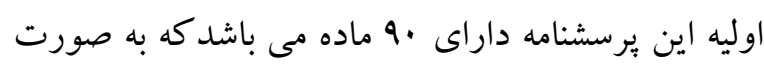

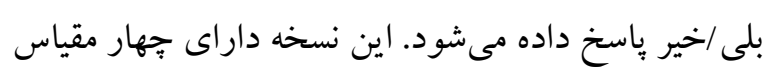

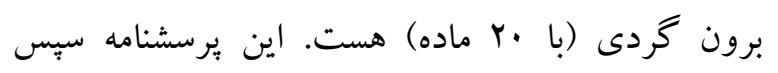
بهوسيلهى آيزنك، آيزنك و بارت (EPQ-R) مورد تجديد نظر قرار كرفت. EPQ-R

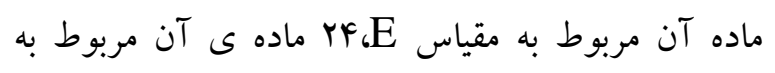

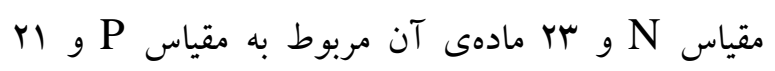

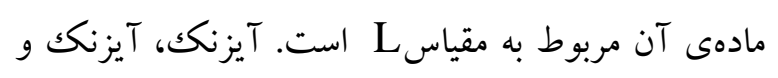

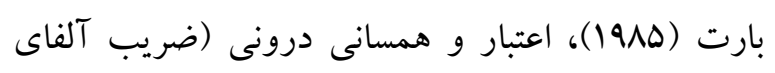
كرونباخ) مقياس هاى LaN،E را به ترتيب در مردان

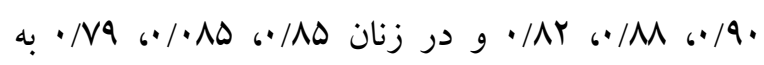
دست آوردند. در ايران ضريب آلفاى كرونباخ در مقياس

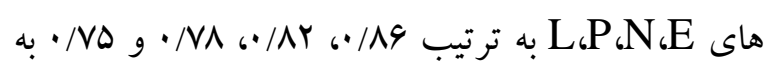

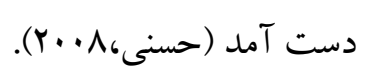

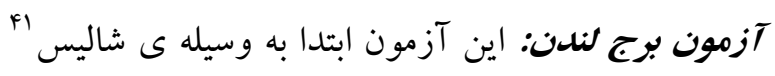

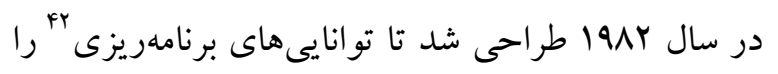
در fl أبيمار با صدمهى لوب فرونتال بسنجيد. آزمون از سه ميله كه روى يكك يايه سطح ثابت شده است و سه مهره با اندازه هاى مختلف تشكيلشده است. آزمودنى بايد با حركت دادن مهرهها روى ميلهها، موقعيت آغازين را به موقعيت هدف تبديل كند. با هفت حركت مى بوان مهرهها از موقعيت A به موقعيت C انتقال داد. براى نمره گذارى آزمون، تعداد حر كاتى كه آزمودنى براى لهو حل مسئله در نظر گرفته (امتياز)، تعداد خطاهايى كه نه

41. Shallic

${ }^{42}$.Planning روش بيزوهش از نوع نيمه آزمايشى و كار آزمايى بالينى است كه با طرح بيش آزمون- يس آزمون با گروه كنترل

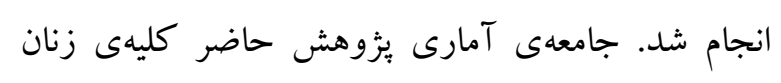
داراى خصيصهى نوروز گرايى در بهار وهبا در اصفهان بود. نمونهها بر اساس نمونه گيرى هدفمند، جمع آورى و

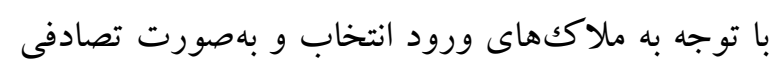

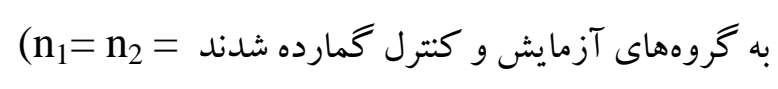

لازم به ذكر است كه جِون در اين مداخله به ارائه برنامه درمانى آموزشى برداخته شد، حجم نمونه بر اساس

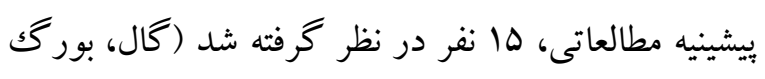

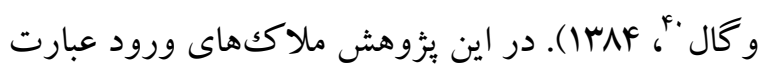
بودند از: جنسيت مؤنث، خصيصهى اضطراب برابر يا بالاتر از r (بر طبق كليد برسشنامه آيزنك)، حيطهى سنى •ه-10 سال، حداقل سطح تحصيلات حداقل ديبلم، باردار نبودن به علت انجام تمرينهاى تنفسى و انقباضى،

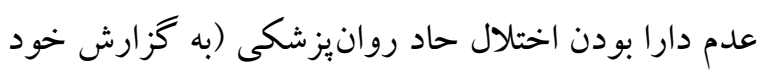
فرد)، دريافت نكردن همزمان رواندرمانى يا يكك برنامه

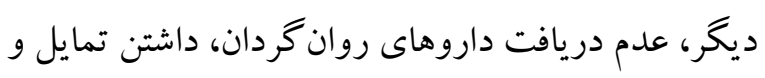
رضايت جهت شركت در جلسات درمانى باهدف يثزوهشى و همين طور ملاككهاى خروج از يثوهش شامل عدم علاقهمندى افراد به ادامه شر كت در جلسات درمانى و غيبت بيش از يكك جلسه از هشت جلسه درمانى بود.

ابزار در اين يزوهش جهت جمع آورى اطلاعات و اندازه كيرى متغيرها از ابزارهاى زير استفادهشده است:

${ }^{40}$.Gall, Borg \& Gall 
• / • بود. قديرى، جزايرى، عشايرى و قاضى طباطبايى يايايى باز آزمايى هر سه كوشش اين آزمون را به ترتيب

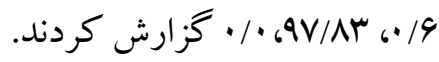

روش در اين مطالعه روش كردآورى اطلاعات بهصورت

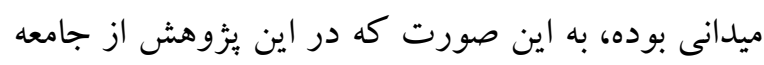

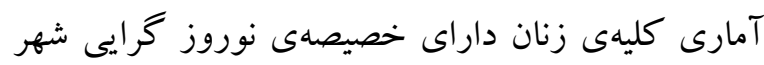

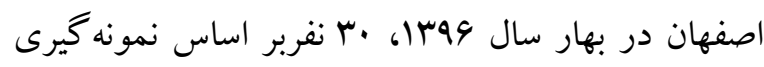
در دسترس انتخاب و بهصورت تصادفى در دو گروه

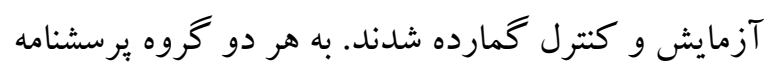
شخصيت آيزنكك و آزمونهاى حل مسئلهى برج لندن و

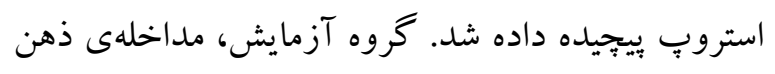
آكاهى مبتنى بر كاهش استرس را بهصورت گروهيى، در هشت جلسه •و دقيقهاى به مدت يكك ماه دريافت كردند و در بايان جلسات درمانى با باز آزمايى مجدد از هر دو كروه تأثير مداخلهى ذهن آكاهى مبتنى بر كاهش بال استرس بروسى شد.
آزمودنى در انجام مرتكب شده و مدتزمانى كه صرف حل مسئله گرديده است، محاسبه مىشود. مطالعات تصويربردارى مغزى با استفاده از شيوههاى PET ،MRI ،FMRI برج لندن به آسيبهاى لوب فرونتال حساس هست. در اكثر يثوهشهايى كه با استفاده از آزمون برج لندن

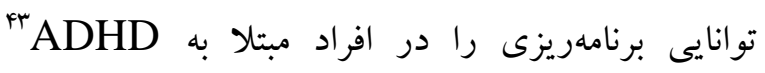
موردسنجش قرار دادهاند به تفاوتهاى معنادارى بين عملكرد آنها در مقايسه با افر اد عادى دست بيداكردهاند. آزمون استروب بِيجيله: در آزمون استروبٍ به معاينه شونده سه كارت ارائه مى گردد. در اولين كارت نقاط الرهون متعددى به رنگك هاى سبز - قرمز - آبى و زرد كذاشته شده و از معاينه شونده خواسته مىشود تا رنگكها را نام ببرد. در كارت دوم كلمات متعددى به رنگكهاى سبز،

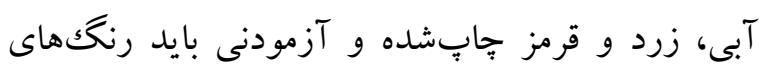
كلماتها را بدون توجه به خود كلمه نام ببرد. در كارت سوم، كلمات سبز، قرمز، آبى و زرد با رنگگ هايى غير از

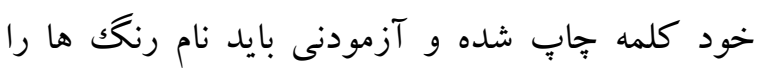
بدون توجه به مفهوم كلمات بيان كند. خطا و زمان لازم براى خواندن هر يكك از كارتها ثبت مىشود. ضريب

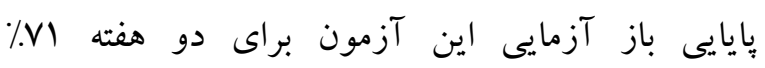
كز ارش شده است.

شاخصهاى موردسنجش در اين آزمون عبارتاند از: (دقت) تعداد بِاسخهاى صحيح (و سرعت) ميانخين زمان واكنش ياسخهاى صحيح در برابر محر كى برحسب هزارم

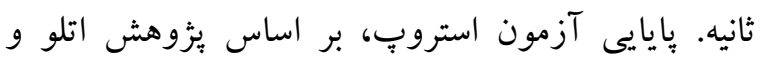
كراف ( آ 1990؛ به نقل ازكريمى و همكاران) به روش باز آزمايى براى هر سه كوشش به ترتيب معادل I • • •، سم/ •،

${ }^{43}$.Attention deficit hyperactivity 
جدول 1- ا: طرح جلسات مداخللى ذهن آكاهى مبتنى بر كاهش استرس

\begin{tabular}{|c|c|}
\hline 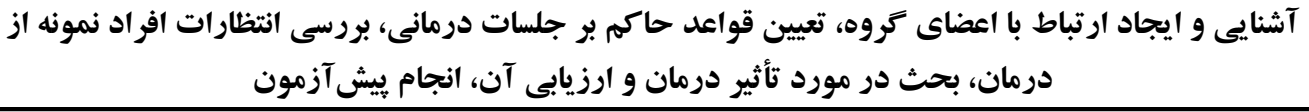 & جلسه اول \\
\hline بررسى ذهن و نظريههاى مرتبط با آن -معرفى ذهن آكاهى - نوع درمان مرتبط با آن و تأثيراتش كاربرد ذهن آكاهى & جلسه دوم \\
\hline تكليف: تمرين تنفس سهدقيقهاى، مراقبه نشسته & جلسه سوم \\
\hline تكليف، تمرين تنفس كوهستان، تمرين نوشتن قضاوتهاى منفى در مورد ديخر ان در يكك هفته اخير & جلسه جهارم \\
\hline تكليف: تمرين وارسى بدن، تمرين نغاه كردن به شمع، انجام تمرينات يو كا (ه مورد) & جلسه هنجم \\
\hline 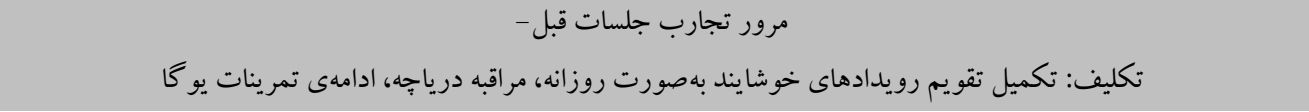 & جلسه ششم \\
\hline 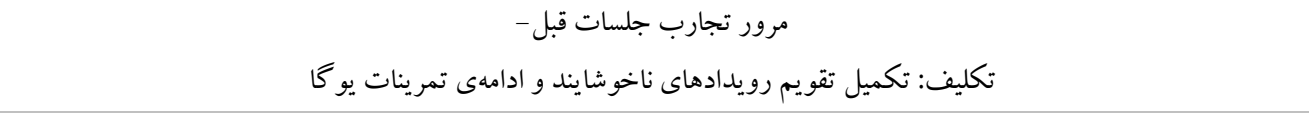 & جلسه هفتم \\
\hline 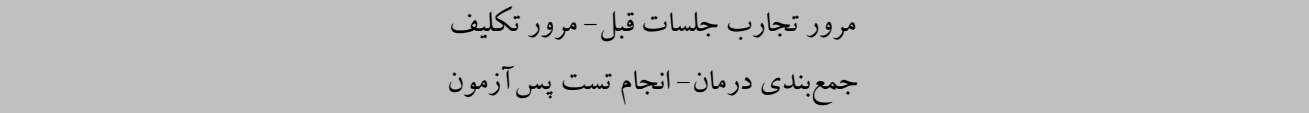 & جلسه هشتم \\
\hline
\end{tabular}

جدول Y يافتهاى توصيفى دو گروه در متغيرهاى مورد

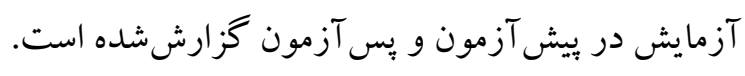

يافتهها

$$
\begin{aligned}
& \text { ميانگين سن شر كت كنند گان در گروه آزمايش بو }
\end{aligned}
$$

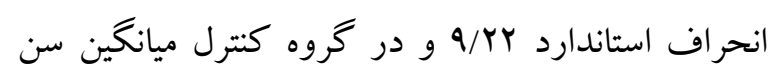

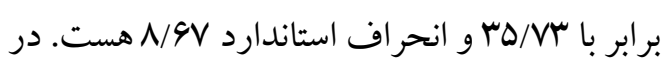

\begin{tabular}{|c|c|c|c|c|c|c|}
\hline \multicolumn{2}{|c|}{ يَ } & \multicolumn{2}{|c|}{ بيش آزمون } & \multirow[t]{3}{*}{ كروه } & \multirow[t]{3}{*}{ 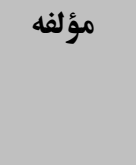 } & \multirow[t]{3}{*}{ متغير } \\
\hline انحراف & ميانكين & انحراف & ميانكين & & & \\
\hline استاندارد & & استاندارد & & & & \\
\hline$\Lambda q / r\rangle$ & $r 9 \Delta / \Delta r$ & YrV/AI & $\Delta F Y / F V$ & آزمايش & زمان كل & كار كرد اجرايى \\
\hline $1 \Delta N / T r$ & FIr/NT & IVW/GY & $F F \cdot / r$. & كنترل & & \\
\hline $1 / 91$ & $r \mid \wedge$. & $r / .1$ & $r V / r$. & آزمايش & & \\
\hline$r / \Delta r$ & YN/YV & r/AY & $r N / T r$ & كنترل & & \\
\hline $1 / \cdot r$ & $1 / N r$ & $r / 09$ & $r / \Delta r$ & آزمايش & نمره تداخل & انعطاف يذيرى شاختى \\
\hline$r / 9 F$ & $\Delta / \varphi$. & $\Delta / \varphi \Delta$ & $\Delta / r$. & كنترل & & \\
\hline
\end{tabular}


نتايج تحليل كوواريانس تعداد بِاسخهاى درست در مر حله بֶ آزمون بِ إز كنترل بيش آزمون در جدول

م ارائهشده است.
بيشفرضهاى تساوى واريانس، نرماليتى و تساوى

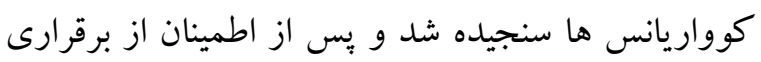
بيشفرض ها، دادهها به روش تحليل واريانس بررسى شد.

جدول ا-"آ: نتايج تحليل كوواريانس تأثير عضويت كروهى بر مؤلفهاى عملكرد اجرايى و انعطافيذيرى شناختى

\begin{tabular}{|c|c|c|c|c|c|c|c|}
\hline توان آمارى & ميزان & معنا دارى & $\mathbf{F}$ & مجذوراتين & آزادى درجه & مجذورات & متغير ها \\
\hline$\cdot / 90$ & $\cdot / \mu F$ & $\cdot / \cdot 1$ & $19 / .4$ & r. $91 \mathrm{r} 4 / 100$ & 1 & r. GAMG/ND & زمان كل \\
\hline$\cdot / 91$ & . Ar &.$\cdots 1$ & MN/F & $11 \mathrm{~V} / \cdot \mathrm{A}$ & 1 & $11 \mathrm{~V} / \cdot 1$ & تعداد ياسخ درست \\
\hline$\cdot \mid \mathrm{YI}$ &.$/ T r$ & $.1 . r$ & \&/AD & SP/DT & 1 & GP/QT & نمره تداخل \\
\hline
\end{tabular}

بنابراين، اين فرضيه كه مداخله ى ذهن آكاهى مبتى بر كاهش استرس، بر انعطاف يذيرى شناختى (نمره تداخل

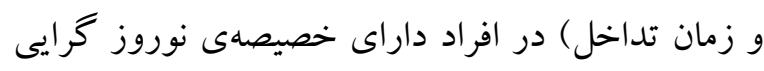
تأثير دارد، براى مؤلفه نمره تداخل مورد تائيد قرار مى گيرد اما براى مؤلفه زمان تداخل مورد تائيد قرار نمى كيرد.

\section{بحث و نتيجه تيرى}

نتايج يزوهش نشان داد كه مداخلهى ذهن آكاهى مبتنى بر كاهش استرس، بر عملكردهاى اجرايى گروه آزمايش نسبت به گروه كنترل در مرحلهى بـ آزمون تأثير دارد. نتايج حاصل با نتايج بهدست آمده از مطالعهى كيانى و هاديان فرد (هوبا)، قادرى نجف آبادى و همكاران

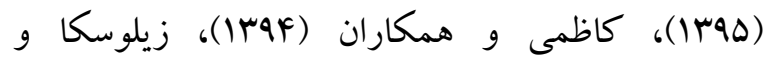

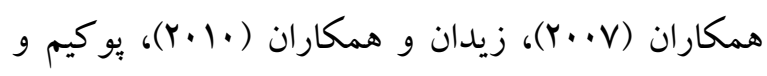

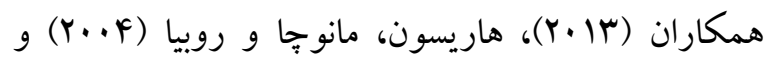

$$
\text { جنسن و كنى (Y. . . F) همسو هست. }
$$

كاركردهاى اجرايى بهعنوان يكك فرايند بيّيجيده كه در آن فرد تحت اجراى يكك سلسله رفتارهاى حل مسئله از

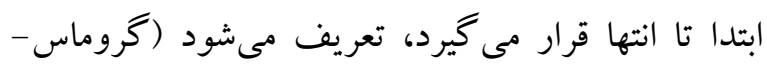

همانطورى كه در جدول ا-ب نشان دادهشده است، يّ از حذف تأثير متغيرهاى همگام (سن، تحصيلات و ورنو ييش آزمون) بر روى متغير وابسته، مشاهده مىشود كه بين

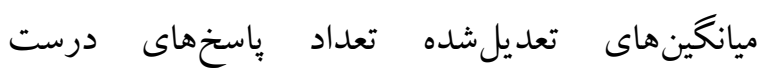

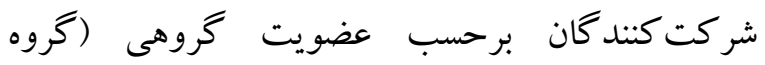
آزمايشى و گروه كنترل) در مرحله يس آزمون تفاوت معنادارى وجود دارد (ه •,P>P). بنابراين اين فرضيه كه مداخلهى ذهن آكاهى مبتنى بر كاهش استرس، بر عملكرد اجرايى و انعطاف بذيرى شناختى (زمان تأخير، زمان آزمايش، زمان كلى و نتيجه كلى) در افراد داراى خصيصهى نوروز گرايى تأثير دارد، مورد تائيد قرار مى كيرد. همانطورى كه در جدول ا-" براى متغير انعطافيذيرى

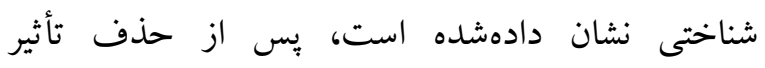

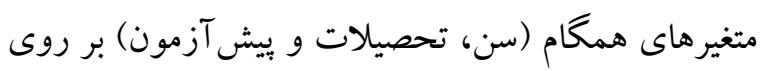

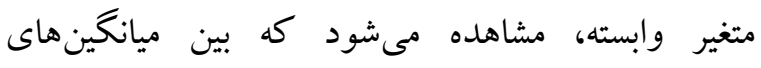
تعديل شده مؤلفه نمره تداخل برحسب عضويت گروهى مُهى

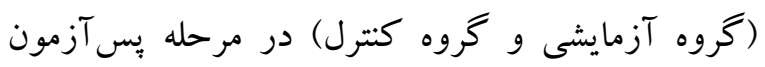
تفاوت معنادارى وجود دارد (هـ, ••P)، اما اين تفاوت براى مؤلفه زمان تداخل معنادار نمىباشد (ه) • (P>). 
rr اثربخشى مداخلهى ذهن آكاهى مبتنى بر كاهش استرس بر عملكردهاى اجر ايى و انعطافيذيرى شناختى در زنان داراى خصيصهى نوروز گرايى در شهر

اصفهان

برنامهريزى كنند. با به كار گيرى اين درمان افراد مى توانند

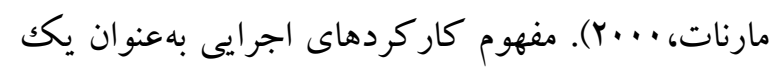

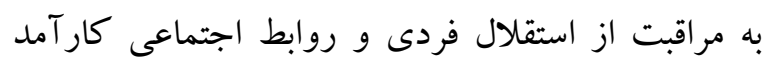
سازهى نظرى توانسته است بين ساختارهاى مغزى (بهويزه يرداخته و شناخت، تفكر و رفتار هدفمند را تنظيم و

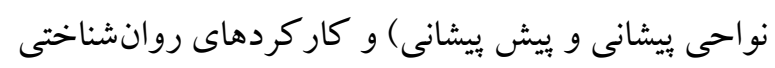
كنترل كنند و به شناسايى و استفاده از راهكارهاى انطباقى

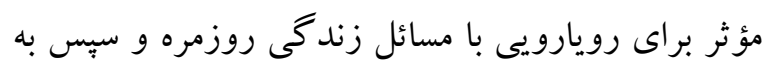
حل مسائل ببردازند؛ بنابراين از بيامدهاى قابلتوجه اين نوع مداخله، افزايش عملكردهاى اجرايى با جهار قلمرو كلى (ادراك، هيجان، شناخت و عمل) هست (مكى إك

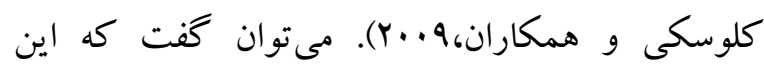
مداخله در بیى آن است كه با افزايش تمركز و دقت، عملكردهاى اجرايى افراد را افزايش داده و بازدهى افراد در حل مسائل تصميم گيرى در امور روزمره را تسهيل كند. نتايج اين يُزوهش نشان داد كه در مرحلهى يس آزمون عملكردهاى اجرايى در افراد داراى خصيصهى نوروز

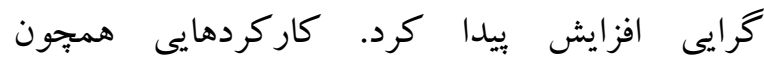

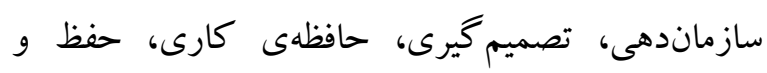
تبديل كنترل حر كتى، احساس و ادراكك زمان، ييشبينى آينده، بازسازى زبان درونى و حل مسئله را مىتوان از جمله مهمترين كاركردهاى اجرايى دانست كه در زندگى و انجام تكاليف يادگيرى و كنش هاى هوشى به

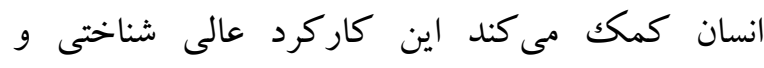
فراشناختى خودتنظيم شونده مىباشند كه مجموعهاى از

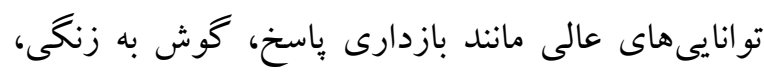

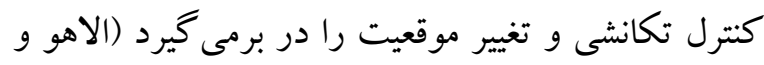

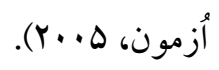
در حقيقت تمرينات ذهن آكاهى مبتنى بر كاهش استرس كه به تنظيم تنفس مى يردازد شامل سه مؤلفه است:

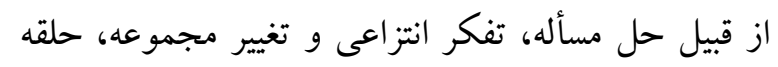

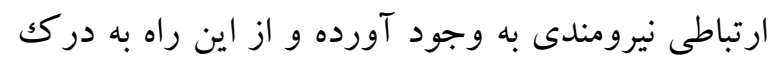

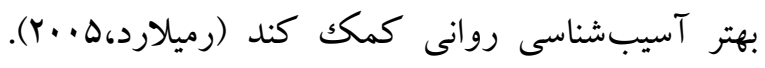
بهور كلى كنشهاى اجرايى درواقع بهمثابه واسطه بين مدارهاى بييجيده عصبى هستند كه ارتباط بين مناطق مجزا در قطعه بيشانى را با ساير مناطق قشرى و زير قشرى است

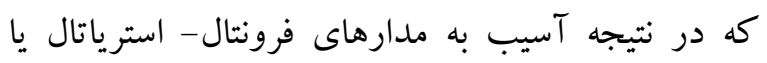
اختلال در سوختوساز اين مدارها به كاركرد اجرايى فرد صدمه مىزند (كإيلان، +. (Y). اين كاركردها به طور مرسوم معادل لوب هاى فرونتال در نظر گرفته مىشوند (استاز و الكساندر، .... (Y). حل مساله يكى ديخر از كاركردهاى عالى ذهن است و شامل مجموعه ييجيدهاى از مؤلفههاى شناختى، رفتارى و

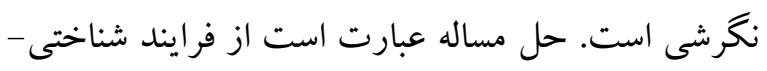
رفتارى خود- هدايتى است كه از طريق آن فرد تلاش مى كند تا راههاى انطباقى و مؤثر را براى مسائل خاصى ركى كه در زندگى روزمره با آنها مو اجهه مى شوند، شناسايى يا كشف كند (شكوهى يكتا، اكبرى زردخانه، برند،

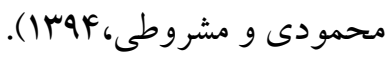

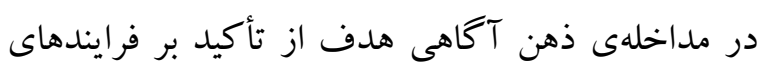
عالى روانشناختى اين است كه جِكونه افراد به مهار

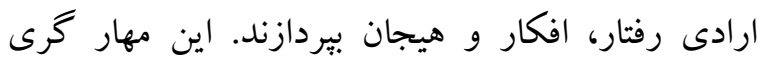
مستلزم استفاده از نيروهاى ذهنى است. در اين درمان افراد ياد مى گيرند بر توجه مداوم تمركز كنند و به افراد كمكك مى كند تا تصميم بـيرند به جه نوع اهداف يا فعاليت هايى توجه كرده و رفتارهاى مطابق با آن را سازماندهى و 
همجنين مىتواند باعث بهبود عملكردهاى حل مساله و

$$
\text { برنامهريزى گردد. }
$$

همجنين نتايج اين بُزوهش نشان داد كه مداخلهى ذهن

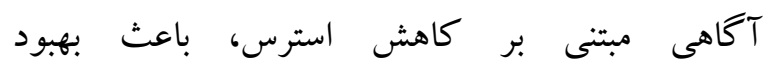
انعطافيذيرى شناختى گروه آزمايش براى مؤلفهى

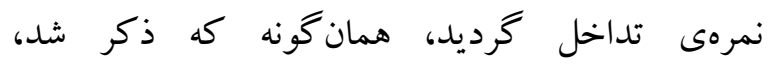
انعطافيذيرى شناختى توانايى افراد در تعديل روند شناخت براى روبرو شدن با موقعيت هاى جديد و غيرقابل ييشبينى است (كانز،r...r). وقتى فرد انعطافيذيرى شناختى نداشته باشد بهطور غيرفعال با شرايط محيط

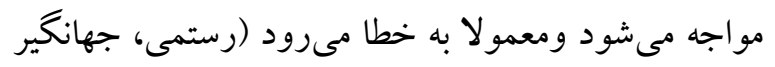
لو، سهرابى، احمديان،هوب(). در اين ئزوهش جهت سنجش انعطاف يذيرى شناختى از آزمون استروب استفاده شد. اين تكليف مستلزم تغيير ذهنى از يكك تكليف به

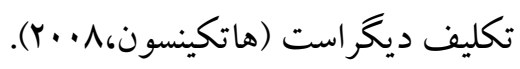
در طى تكليف استروٍ از شركت كنند گان خواسته مىشود بهجاى معناى كلمات، به رنكى توجه كنند كه كلمات با آن نوشتهشدهاند. وقتى از شركت كنند كان

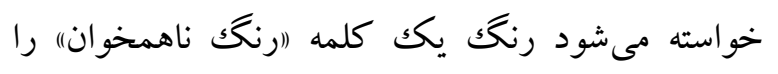
شناسايى كنند، واكنشهاى آنها به طور معنادارى آرام تر و داراى دقت كمترى نسبت به زمانى است كه به

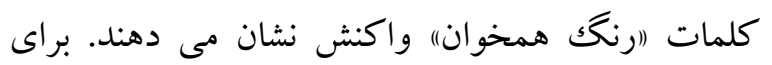
اينكه وقتى شركت كنند گان با كلمات ناهمخوان مواجه مىشوند بِاسخ درست بدهند، فعالسازى خود كار معناى كلمه بايد ناديده گرفته شود و ازآنجا كه در خواند بندان

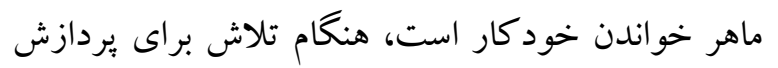
كلمات (رنگك ناهمخوان) افزايش زمانهاى واكنش و و خطا در فعاليت آنها مشاهده شود. اثر استروبٍ دشوارى
كسترش آرامش، تمرين براى كنترل تنفس و مراقبه به بهنوان يك مداخلهى ذهن - بدن. تأكيد اين درمان بر آرامسازى است و تمرينات آن بهصورت ايستا و ويويا انجام مىشود كه متمايز از تمرينهاى معمولى هست. ذهن آكاهى بهطور منظم باعث انقباض و استراحت بيوسته عضلات در انجام حر كات، تغيير الكوى تنفسى، برورش توجه و هوشيارى ذهنى،

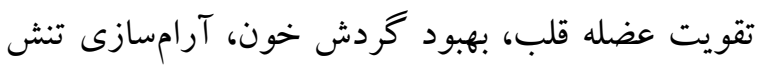
عضلات و رهايى ذهن از استرس و هيجانات منفى در طول تمرين مىشود (وارما و راجو، Y|+r) و در نتيجه منجر به بهبود رفتار انطباقى در برابر شرايط محيطى شود. به اين دليل كه كاركردهاى اجرايى به نوعى به فرايند ذهن و توانايى كنترل جسم، شناخت و هيجان براى

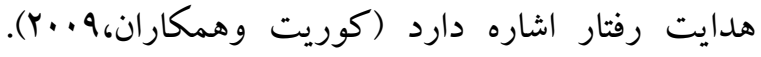
كنترل ذهن با تمرين هاى بودن در زمان حال و كنترل جسم (تمرين اسكن بدن) مىتواند بهبود عملكرد اجرايى به طور كلى كمك كند. بهبود عملكرد قشر يِيشانى مى تواند منجربه بهبود كنشهاى اجرايى شود. در افراد مضطرب بخصوص بهبود تنفس نقش قابلتوجهى در كاهش اضطراب دارد كه هم منجر به بهبود كنشهاى شناختى و هم منجر به بهبود خلق مىشود. تمرين تنفس به آزادسازى ذهن از

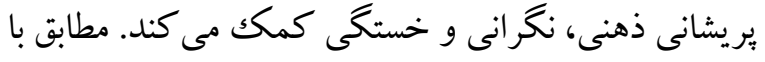

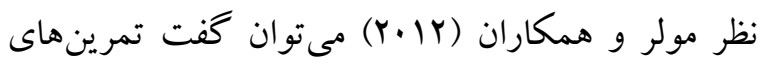
آرامسازى با بهبود گردش در غدهى درونريز، عملكرد هورمونهاى اصلى را كه نقش اصلى در فيزيولوزى مشكلات خلقى ايفا مى كنند را بهبود بخشيد ه و بهطور غيرمستقيم از طريق بهبود خلق بر عملكرد اجرايى تأثير

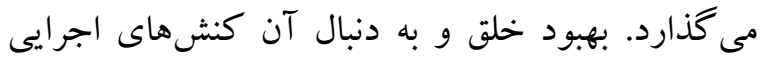


فو اصل قبل و بعد از مداخله بررسى شدند اما جندين ماه

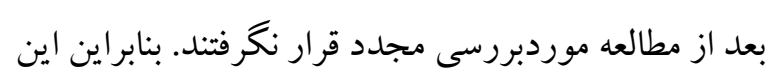
يُزوهش فاقد دورنى بيگيرى هست، روبرو بود؛؛ بنابراين

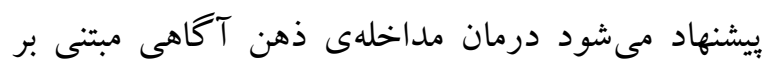
كاهش استرس در يُزوهشهاى آتى در تركيب با ساير روشهاى درمانى اضطراب مورداستفاده قرار كيرد. همجنين اين يُوهش در ساير اختلالات و در ارتباط با هر دو جنس انجام گيرد. بيشنهاد مى شود جهت ارزيابى تأثير طولانى تر زمان برماندگارى درمان، ئزوهشى با مدت زمان ييخيرى طولانى تر اجرا شود.

\section{Refrences}

Ajilchi,B., \&Nejati,V., 2013. Attention bias to sad faces and images: which is better for redicting depression? Open Journal of depression,vol. 2, no.3,pp.19-23. (persian)

Akhari,A., Rostami,M., Hashemi, T.,\& Vahid Haji Agaie Nia, B., 2013. Relationship of family features, coping styles and stressor life events with suicide attempt, J Res Behave Sci, vol.12,no. 2,pp.156-157. (persian)

Amiri,M., Rabiei, M.,\& Donyavi,V., 2016. Effectiveness of mindfulness training in enhancing executive function and decreasing symptoms of depression and anxiety in patients with multiple sclerosis (MS). Joumal of behavioral and brain science,vol. 6, pp.,329336. (Persian).

Atadokht, A., Jafarian Dehkordi, F., Basharpoor, S., \& Narimani, N., 2015.Effectiveness of Transactional Analysis Training on Cognitive Fexibility and Family Function in Women With Marital Disputes, Journal of personality \& Individual Differences,vol.4,no. 8, pp.28-30. (persian)

Chambers,R.,Gullone,E., \&Allen,N.B., 2009. Minful emotion regulation: An integrative review. Clinical psychology review,vol.29,pp. 560579.
قطع فرايند خود كار خواندن كلمات در خوانند گان ماهر

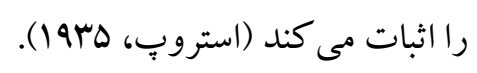
توضيح ديخر اينكه برون داد يك بِاسخ وقتى بِديد

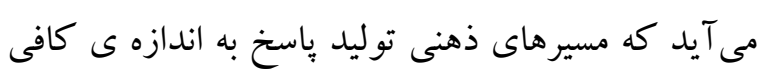

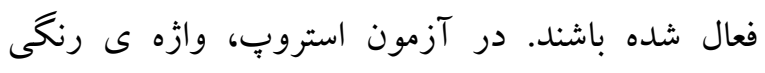
مسيرى را در قشر مخ براى نام بودن آن وازه فعال مى كند، اما مسير قبلى با مسير بعدى تداخل مى كند. در جنين موقعيتى زمان بيشترى لازم است تا به اندازه ى كافى فعال سازى قوت گيرد و بِاسخى مبنى بر نام بردن رنگگ و نه

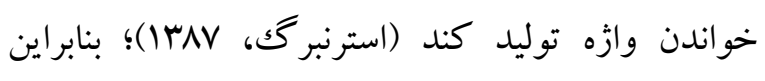
افزايش عملكرد (كاهش خطا و زمان واكنش) دراين تكليف نيازمند سرمايه كذارى مجدد توجه (غير

خود كارسازى) و وِاسخى غيرعادتى است (مورى و و

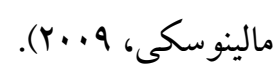
تحقيقات بيان مى كند كار كردهاى اجرايى نقش مهمى در كنترل انعطاف يذيرى شناختى درهيجان و عمل دارد و براى زندگى روزمره بسيار حياتى است (كلستانى فرد،

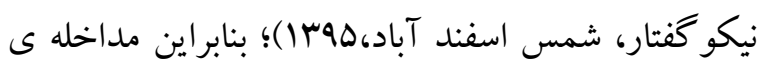
ذهن آكاهى مبتنى بر كاهش استرس مى تواند با بهبود

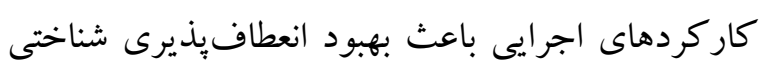
كردد. از طرف ديخر جون اين آزمون مستلزم كنترل توجه است و مداخله ذهن آكاهى منجر به بهبود توجه

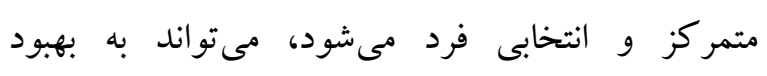
انعطاف يذيرى كمك كند. اين يزوهش با محدوديتهايى مانند اينكه بثزوهش صرفاً

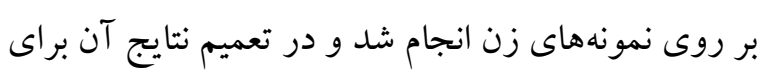
مردان، بايد جانب احتياط را رعايت كرد. همجنين يثوهش بر اساس نمونه گيرى در دسترس بوده و در تعميم نتايج بايد احتياط كرد. در اين مطالعه آزمودنىها در برد 
Cramer, H.,Haller, H.,Lauche, R., \&Dobos,G.,2012. mindfulness- based stress reduction for low back pain. A systematic review. BMC complementary and Alternative medicine,vol.12,no. 162,pp. 2-8.

Fazeli, M., Ehteshamzadeh, P.,\& Hashemi Sheikh Bahani, E.,2013.The effectiveness of cognitive behavior therapy on cognitive flexibility of depressed people,. Journal of Thought \& Behavior in Clinical Psychology,vol. 9,no. 34, pp.28-29.(Persian)

Finu cane, A., \&Mercer,S.W., 2006. an exploratory mixed methods study of the acceptability and effectiveness of mindfulness- based cognitive therapy for patients with active depression and anxiety in primary care BMC psychiatry,vol. 6,no. 14,pp.1-14.

Friese,M.,Messneer,C., $\quad$ \&Schaffiner,Y.,2012. Mindfulness meditation counteracts selfControl depletion. Condciousness and cognition , Behaviour research and therapy,vol.21, pp.1016-1022.

Garibring,p., Apelstraand, M., Sehlin, H., Amir, N.,Rousseau, A., Hofmann,S.G.,\& Andersson,G., 2012. intemet- delivered attention bias modification training in individuals with social anxiety disorder-a double blind randomized controlled trial. BMC Psychiatry, pp.2-9.

GHaderi najafabadi, M., Soleimani najafabadi,M., Moradisorosh, M.\& Habibolahi, S., 2016. The Effectiveness of Mindfulness Techniques Training on Life Orientation, Life Satisfaction, and Acceptance and Action in Addicted Women UndergoingRehabilitation, J Res Behav Sci,vol. 14, no.1,pp.41-43.(Persian)

Golestanifard, M., Nikogoftar, M.,\& Shams sfandabad, H., 2016. A Comparison of Executive Functionsand Memory in Bilingualand Monolingual Student, Social Cognition,vol.1, no. 9, pp.51-54.(Persian).

Greeson, J. M., Brainard, G. C.,\& Rosenzweig, S., 2001. Mindfulness based stress reduction quality of in aheterogeneous patient population. General HospitalPsychiatry,vol.23, pp. 183-192.
Kazemi,M., Amiri, SH., Malekpoor, M.,\& Molovi, H., 2016. Comparing the Effect of Personal Speech Education on the Executive Function of Students with Attention Deficit and Normal, Psychology of Exceptional Children, vol.5, no. 19, pp.24-29.(Persian).

Kiyani, B.,\& Hadyanfard, H., 2017. The Impact of Intervention Based on Mindfulness on Planning of Adolescents with Subthreshold Symptoms of Attention Deficit-Hyperactivity Disorder in Tower of London Test. Journal of Management System, vol.7, no.23, pp.116118.(Persian).

Kong,F., wang, xu., \&zhao,J., 2014. Dispositional mindfulness and life satisfaction: The role of core self- evaluation. Personality and individual differences,vol.56, pp.165-169.

Latzman, R.D., \&Masuda.A., 2013. Examining mindfulness and psychological inflexibility within the frame work of Big Five personality,personality and individual differences, Behaviour research and therapy,vol.55, pp.129-134.

Lerner,R.,Kibler,J.L., \& Zeichner, S.B. 2013, Relationship between mind fullness- Based reduction and immune Function in cancer and HIV/AIDS. Cancer and clinical oncology,vol.2, no. 1,pp. 62-72.

Lin,M.,\&Tanno, Y., 2012. Enhancing effect of postLearning stress on memory. Psychology, vol.3, no.5, pp.419-423.

Marteau,F.,

Lassalle, A.S.,Vilette,B.,servant,D.,\&Rusinek,S., 2012. Emotional bias in childhood-event interpretation by adults with generalized anxiety disorder. Open Joumal of Medical psychology,vol.1,pp.25-31.

Mullur, L.M., khodnapur,J.P., Bagali, sh.C.,\& Aithala,M., 2012. influence of yogo pracyice on anxiety level of apparently healthy female subjects of bijapur (karnataka). International Journal of biomedical and advance research,vol. 3, no. 8, pp.618-820.

Nezlek,J.B.,Holas, P.,Rusanowska,M., \&L rejtz,I., 2016. Being present in the moment: event-level relationships between mindfulness and 


$$
\text { وب اثربخشى مداخله ذهن آكاهى مبتنى بر كاهش استرس بر عملكردهاى اجرايى و انعطافيذيرى شناختى در زنان داراى خصيصهى نوروز گرايى در شهر }
$$

اصفهان

stress,positivity and importance. Personality and individual differences.Journal of contextual behavioral science,vol.93, pp.1-5.

Noferesti, A., Parhoon, H., \& Momeni, KH., 2014. Cognitive inflixibility and problem solving styles among ruminative and nonnuminative students, Advances in Cognitive Scienc, vol.16, no.3, pp.32-33.(Persian).

Noranijoorjadeh, R., Mashhadi, A., Tabibi, Z, \& KHirkhah, F., 2016. Effectiveness of Executive Functions Training Based on Daily Life on Executive Functioning in children with Attention Deficit / Hyperactivity Disorder. Advances in Cognitive Sceince, vol. 18, no. 1, pp. 68-70(Persian).

Omidvari, S., Azin, A., Montazeri, A., Sedighi, z., Jahangiri, K., Ayeenparast, A., Farzadi, F., Ebadi, M., Mafton, F.,\& Vahdaniniya, M., 2012. Anxiety attribute in the general population" Study of health from the perspective of the Iranian people". Quarterly Journal of the Institute of Health Sciences, Jihad University,vol.10, no.3,pp. 375-373.( Persian).

Past, N.,\& KHosravi,Z., 2015. The Investigation of Planning Function in Patients with Obsessiv Compulsive Disorder and Obsessive Compulsive Personality Disorder, Advances in Cognitive Science,vol.17, no. 3, pp.24.(persian).

Rafieeniya, P., Zahmatbar,S., Rahimiyanbogar, E., Asadi,O., \& Kazemihaghighi, N., 2014. The Comparison of Executive Function in Prisoners with Antisocial Personality Disorder and Normal Individuals. Joumal of Clinical Psychology, vol. 2, no. 18, pp. 45-47.(persian).

Schwab,s.,Memmert,D., \&Roy,M.M., 2013. The effect of motivation and attention on bias in memory for duration, Joumal of Abnormal Psychology,vol.4,no. 2,pp.83-87.

SHokohiyekta, M., Akbari zardkhaneh, S., Parand, A., Mahmoodi,M., \& Mashroti, p.,2016. Effect of Teaching Problem Solving to Mothers on Family Processes and Parenting Styles,Quarterly Joumal of Child Mental Health,vol.3, no.1,pp.29-32.(persian).
Souza,I.,pinheiro.M.A.,\&Mattos, P., 2005. Anxiety disorders in an attention deficithyperactivity disorder clinical sample. Arq Neuropsiquiatr, vol. 63, no. 2,pp. 407-409.

Szanton, s., Wenzel, J., Connolly, A.B., Piferi, R.L., 2011. Examining mindfulness-based stress reduction: perceptions from minority older adults residing in a low- income housing facility. BMC Complementary and Altemative medicine,vol. 11, no. 44,pp.2-7.

Taziki, M., Alizadeh, H., Hakimirad, E., Farokhi, N.A.,\& Moghadas, A., 2014. Comparison of executive functions of orphanages with ordinary children. Advanced in New Cognitive Science, vol.4, pp. 64-65.(persian).

Tovilovic, S., Novovic, Z., Mihic, L., \& Jovanovic,V., 2009. The role of trait anxiety in induction of state anxiety. Psihologija, vol.42, no. 4, pp.491504.

Vasson, J., Nyklicek, I., pop, V JM., \&Pouwer,F., 2011. Testing the effectiveness of a mindfulnessbased intervention to veduce emotional distress in outpatients with diabetes (Diamind): design of a randomized controlled trial. BMC bublic Health, vol.11, no. 131,pp. 2-11.

Viden, L.L., singer, H.O., Cohen, N., Todder, D., Aue, T., Nemets, B., \& Henik,A., 2016. Attentional bias in clinical depression and anxiety : The impact of emotional and non-emotional distracting information.Biological psychology, vol.7, no. 12, pp. 1-8.

Walsh,JJ.,Balint, M.G.,Smolira, SJ.D.R.,Fredericksen, L.K.\&madsen, s., 2009. predicting individual differences in mindfulness: The role of trait anxiety, attachment anxiety and attentional control, personality and individual differences,vol.46, pp.94-99.

Waters,L., 2016. The relationship between child stress, child mindfulness and parent mindfulness. Psychology,vol.7,pp.40-51.

Yochim,B.P.,Mueller, A.E.,\&segal , D.L., 2013. Late life anxiety is associated with decreased memory and executive functioning in community dwelling older adults. Joumal of anxiety disorders,vol.27, pp.567-575. 
Zeidan, F., Grant, J.A., Brown, C.A., MCHaffie, J.C., \& coghill, R.C., 2012. Mindfulness meditationrelated pain relief: Evidence of unique brain mechanisms in the regulation of pain, Neuroscience Letters, vol.520, pp.165-173.

Zeidan, F., Johnson, S.K., Diamond, B. J., David, Z, \& Goolkasian, P., 2010. Mindfulness meditation improves cognition: Evidence of brief mental training consciousness and cognition, conscious and cognition,vol.19, pp.597-605.
Zunhammer, M., Eberle, H., Eichhmmer, P., \& Busch, V., 2013. Somatic symptoms evoked by exam stress in university students: The role of alexithymia, neuroticism,anxiety,vol.8, no. 12, pp.1-11.

Zylowska, L., Yang, M.H., Futrell, J.L., Horton, N.L., Hale, T.S., Pataki, C., \& Samlley, S.L., 2007. Mindfulness meditation training in adults and adolescents with ADHD. Joumal of attention disorders,vol. 19, pp.1-10. 